\title{
HUMAN RESOURCE DEVELOPMENT POLICIES FOR PWD (Persons With Disabilities) EMPLOYEES IN SOUTH CENTRAL RAILWAYS
}

\author{
Dr Kiran Das Naik Eslavath \\ Assistant Professor \\ Center for Research and Strategic Studies \\ Lebanese French University
}

\begin{abstract}
Service sector in India consists of a wide variety of services such as electricity, water supply, road, rail and air transport etc which provides a vast opportunities for HRD. Indian Railways is the backbone of service sector and one of the biggest employers in India. Indian Railways is one of the gigantic public undertakings enriched with fixed assets. The universe constitutes the PWD employees of South Central Railway. The total universe of the organization is 1120 employees of various departments shown in table. The sample size taken from the universe for the study is 50\% i.e. 560 respondents. The analysis results that the most of the respondents are neutral in opinion in all the aspects of potential appraisal, career development and job rotation. They disagree with some of the aspects of training and development, performance appraisal and promotions and transfers.
\end{abstract}

Keywords: Service Sector, Indian Railways, Human Resource Development.

\section{INTRODUCTION}

It is logically presumed that the perception of those vested with the responsibility of formulating and implementing the HRD policies and the perception of those who are the beneficiaries tend to be different and further, such differential perceptions are considered as having significant implication for their orientation towards HRD policies and practices.

HRD policy lay down the broad guidelines for doing about the HRD practices and streamlines the organizational priorities with regard to the personnel matters. These policies provide much needed orientations and framework for HRD practices to unfold. As such it is logically assumes that, the HRD practices are the reflection and functions of the HRD policies.

Further, it is logically assumed that the perception of the employees about the HRD and situation could provide invaluable insights into the HRD climate in the organisation. Hence, along with HRD policies, an attempt is made in this study to ascertain HRD policies functioning in the South Central Railway. 


\section{HRD PRACTICES IN SCR:}

Human resource is critical for the efficient functioning of the railways. At present, the SCR have total staff strength of 88614 . They are being equipped to cope with the changing environment, with the induction of better technology, work practices, automation and computerization to ensure safe, reliable operations. The study endeavors to portray and analyse HRD practices like training, performance appraisal, HRD Culture and Climate, Motivational Practices and so on.

\section{Review of Literature}

Dr. Manisha Seth and Dr. Deepa Sethi $(2011)^{1}$ In their article reviles "Human Resource Outsourcing: Analysis Based on Literature Review" focuses on different types of HR outsourcing and the factors which need to be considered before a company goes for outsourcing of Human resource Functions.

Dr. Muhammad Tariq Khan Dr. Naseer Ahmed Khan Khalid Mahmood (2012) ${ }^{2}$ In their paper entitled "An Organisational Concept of Human Resource Development How Human Resource Management Scholars View 'HRD”. HRD is an important topic of present time. It is considered by management professionals, as sub discipline of HRM, but many researchers have, broadened the scope and integrated the concept of HRD by looking it from socio economic angle and giving it other dimension such as physical, intellectual, psychological, social, political, moral and spiritual development.

Sanaya Khanna $(2013)^{3}$ In his study "Human Resource Challenges and Opportunities in Indian Railways" Service sector in India which consists of a wide variety of services such as electricity and water supply, road, rail and air transport, hospitals, police, postal department, call centers etc., is a real challenge for HRD. Indian Railways is the backbone of service sector and one of the biggest employers in India. The network of IR is very vast, spread all over India. Due to this widespread network, it brings in its fold people from different origins and of different workforce profile working together under one roof. This necessitates the prevalence of different HR practices in order to deal with them effectively so that their full potential may be explored.

\section{RESEARCH METHODOLOGY} Statement Of The Problem

\footnotetext{
${ }^{1}$ Dr. Manisha Seth and Dr. Deepa Sethi "Human Resource Outsourcing: Analysis Based On Literature Review", International Journal of Innovation, Management and Technology, Vol. 2, No. 2, April 2011, pp 127-129.

${ }^{2}$ Muhammad Tariq Khan Dr. Naseer Ahmed Khan Khalid Mahmood (2012), “An Organisational Concept of Human Resource Development - How Human Resource Management Scholars View 'HRD”.Universal Journal of Management and Social Sciences, Vol. 2, No.5; May 2012.

${ }^{3}$ Sanaya Khanna“Human Resource Challenges and Opportunities in Indian Railways"Indian Journal Of Research, Advance Access publication 18 July. 2013, pp 07-12
} 
The present study deals with the Human Resource Development Practices for P.W.D (Persons with Disabilities) Employees in South Central Railways Secunderabad Division. For evaluating the human resource development activities for persons with disabilities employees in south central Railways, the researcher has chosen to study at, Secunderabad Division. The study assumes assessment of activities like HRD practices like, Training, Performance Appraisal, Promotional Policies, Transfers, Reward Management. Therefore, the research problem has been stated as Human Resource Development Practices for persons with disabilities employees in Indian Railways - A case study with reference to South Central Railways, Secunderabad Division.

\section{Significance Of The Study}

Indian railways are major contributor in generating the employment facilities for Persons with disabilities at different levels and also it is rendering its services to the people living in the country. To render these services effectively to the utmost satisfaction of the people, the railways must be manned by efficient and committed employees with required level of skills and knowledge. The changing trends in transport industry necessitate Indian railways to play a crucial role in providing various passenger services. As a result, the Indian railways require efficient and committed human resources to discharge the functions effectively and tactfully. This emphasizes as the significance of human resource development practices for PWD (Persons with disabilities) employees in Indian railways. This study attempts to examine the present state of human resource development practices, analyze the defects therein and offer suggestions for effective human resource development practices for PWD (Persons with disabilities) employees in Indian railways. The review of literature presented above reveals there are very few studies concentrated on Human Resource development practices. In particular there are no studies on Human Resource development practices for PWD (Persons with disabilities) employees in Indian railways - A case study with reference to south central railways Secunderabad Division. Hence, the study assumes greater significance and there is need to study on human Resource development practices for persons with disabilities employees in Indian Railways in general and in Secunderabad Division in particular.

\section{Research Gap Of The Study}

Even though there are many research theses on railway employees and also on Human resource Development practices on Indian railways. But there are no studies available in particularly on persons with disability employee's human resource development practices. So the researcher made an attempt to fill the research gap for studying entitled Human resource development practices for PWD employees in Indian railways- a case study in south central railways Secunderabad Division.

\section{Need For The Study}

In the present scenario the world is become a global village so the educational standards and employment opportunities have been increased a lot. The disabled persons are also become a good educators and competitors, both in national and international level. Especially in the Indian government sector there is a reservation 
facility of 3\% for disabled persons and it enhances a lot to get employment opportunities for disabled persons but their needs and requirements or facilities always differ from others. Indian railways happened to be the back bone of the Indian economy and also the biggest employable sector. Based on this employability reservation of $3 \%$ Indian Railways sector has big number of disabled employees. Hence this is the right time and right topic to study and make good suggestions for disabled employees' in related to Human Resource Development Practices.

\section{Scope Of The Study}

The study is to know the opinions of the respondents about the Human Resource Development Practices for PWD (Persons with Disabilities) employees of organization under study. The scope of the study covered the area of, human resource development. The study has been limited to PWD employees of South Central Railways of Secunderabad Division. The study entitled as "Human Resource Development Practices for PWD (Persons with Disabilities) Employees in Indian Railways (A Case Study with Reference to South Central Railways Secunderabad Division)."

\section{Objectives}

1. To assess the Human Resource Development Practices - Training \& Development, Performance Appraisal, Potential Appraisal, Career Development, Promotions \& Transfers and Job Rotation of P.W.D. Employees in South Central Railway.

2. To offer suggestions to improve the Human Resource Development Practices of P.W.D. Employees in South Central Railway.

\section{Hypothesis}

HO: There is no statistically significant difference in the mean opinion of human resource development practices variables and designation of the respondents.

$\mathrm{H}_{1}$ : There is a statistically significant difference in mean opinion of human resource practices variables and designation of the respondents.

$\mathrm{H}_{0}$ : There is no statistically significant relation between human resource practices variables and nature of disability of the respondents.

$\mathrm{H}_{2}$ : There is statistically significant relation between human resource practices variables and nature of disability of the respondents.

\section{Methodology Of The Study}

Methodology of the study is a way to systematically solve the research problem. Application of appropriate methods and adoption of scientific procedure is essential of systematic enquiry. The present study uses different methods to analyse the data.

\section{Study Area}

The study area covers the Human Resource Management Practices for PWD (Persons with Disabilities) Employees of South Central Railways of Secunderabad Division. 


\section{Pilot Study and Checking the Reliability}

A pilot study has been done on 50 respondents of South Central Railways in order to evaluate feasibility, time, cost, adverse events, and affect size (statistical variability) to predict an appropriate sample size and improve upon the study design prior to performance of a full-scale research project. The very process has been repeated among the same respondents as part of the study after a gap of three months and the reliability in their response has been found very high.

\section{Method of the study}

Application of appropriate method and adoption of scientific procedure is essential for any systematic enquiry. This has an important bearing on the collection of reliable and accurate information as well as on the outcome of the study. The present study uses a survey method.

\section{Sampling Method and Sample}

The researcher has used simple random sampling technique for the study. The universe and sample size of the study is as shown in the below table.

The universe constitutes the PWD employees of South Central Railway. The total universe of the organization is 1120 employees of various departments shown in table. The sample size taken from the universe for the study is $50 \%$ i.e. 560 respondents.

\section{Data Collection}

The data has been collected from employees of South Central Railways of Secunderabad Division on the basis of both primary and secondary data.

\section{Primary Data}

To fulfill the objectives and to test the hypothesis, primary data is collected from the employees by using self-administered questionnaires. Personal interviews and observations are also the primary source of data collection in this study.

\section{Questionnaire}

The questionnaire is often used as observational device for collecting personal data and opinion it provides a way to collect personal information from respondents that may not be readily obtainable using other methods. The instrument used under study has 105 questions which were grouped into four variables. The questionnaire is divided into two. The first part is demographic profile and the second part is Human Resource Development Practices. Under each variable, there are sub-variables which have five statements each. Questionnaire was framed in the Likert-5-point scale.

\section{Secondary Data}

Secondary sources are those sources which covers that data that have gather and assembled for some another purpose. The possible sources of secondary data are already compiled statistical statements and reports whose data may be used by 
researcher for his studies. Secondary data provides the knowledge about the organization in terms of facts it also provide information about the importance and effectiveness of the topic. For the purpose of this study, secondary data is collected from the following sources:- Journals, Magazines, Books and Websites etc.

\section{Processing of the data}

The study of Human Resource Development Practices for PWD (Persons with Disabilities) Employees of South Central Railways of Secunderabad Division is processed through the qualitative and quantitative of the data.

\section{Statistical Tools}

For this study the researcher has used the Simple Frequency Distribution followed by Descriptive Statistics - Mean, Standard Deviation and One-Way ANOVA Test.

\section{Discriptive Statistics}

Table-1

Descriptive Statistics for Training and Development

\begin{tabular}{|l|l|l|l|l|l|}
\hline & $\mathbf{N}$ & $\begin{array}{l}\text { Minim } \\
\text { um }\end{array}$ & $\begin{array}{l}\text { Maxim } \\
\text { um }\end{array}$ & Mean & SD \\
\hline $\begin{array}{l}1 \text { Knowledge Skills and Attitude are the focus } \\
\text { of Training and considers the employee } \\
\text { learning needs }\end{array}$ & 560 & 1 & 5 & 2.58 & 1.315 \\
$\begin{array}{l}2 \text { Training enables employees to perform the } \\
\text { job effectively }\end{array}$ & 560 & 1 & 5 & 2.37 & 1.186 \\
$\begin{array}{l}3 \text { Training feedback is given to employees } \\
\text { they take it seriously and use it for } \\
\text { development }\end{array}$ & 560 & 1 & 5 & 2.92 & .932 \\
$\begin{array}{l}4 \text { The training is effective enough to practice } \\
\text { its content on the job with ease }\end{array}$ & 560 & 1 & 5 & 2.22 & 1.176 \\
$\begin{array}{l}5 \\
\text { Erograms are given opportunities to try out } \\
\text { what they have learned } \\
\text { Valid N (list-wise) }\end{array}$ & 560 & 1 & 5 & 2.84 & 1.180 \\
\hline
\end{tabular}

The table 1. Explores the mean and standard deviation for Training and Development. The highest mean value is 2.92 and the lowest standard deviation is 0.932 for Training feedback is given to employees they take it seriously and use it for development. The lowest mean value is 2.22 for the training is effective enough to practice its content on the job with ease. The highest standard deviation is 1.186 for Training enables employees to perform the job effectively. Across the observations, the descriptive statistics for Training and Development in South Central Railway depicts that the majority of the respondents are disagree in opinion with high variation. 


\begin{tabular}{|c|c|c|c|c|c|}
\hline & $\mathbf{N}$ & $\begin{array}{l}\text { Minim } \\
\text { um }\end{array}$ & \begin{tabular}{|l} 
Maxim \\
um
\end{tabular} & Mean & SD \\
\hline $\begin{array}{l}6 \text { The performance appraisal system } \\
\text { provides an opportunity for each appraisee } \\
\text { to have a clear understanding of what is } \\
\text { expected by the reporting officer during the } \\
\text { performance year. } \\
7 \text { The performance appraisal system }\end{array}$ & 560 & 1 & 5 & 2.71 & 1.050 \\
\hline $\begin{array}{l}\text { superiors to perform the job well through } \\
\text { performance review discussions }\end{array}$ & 560 & 1 & 5 & 2.73 & 1.247 \\
\hline $\begin{array}{l}8 \quad \text { The performance appraisal system } \\
\text { encourages the appraiser and appraisee to } \\
\text { have a common understanding of the factors } \\
\text { affecting the performance of the appraise }\end{array}$ & 560 & 1 & 5 & 2.42 & 1.249 \\
\hline $\begin{array}{l}9 \text { The performance appraisal system has } \\
\text { scope for reflection and assessment of each } \\
\text { appraisee on the personality factors and } \\
\text { attributes required for the present job of the } \\
\text { assessee. }\end{array}$ & 560 & 1 & 5 & 2.68 & 1.214 \\
\hline $\begin{array}{l}10 \text { The performance appraisal system helps } \\
\text { interested appraisees to gain more insights } \\
\text { into their strengths and weaknesses. }\end{array}$ & 560 & 1 & 5 & 2.63 & 1.199 \\
\hline Valid N (listwise) & 560 & & & & \\
\hline
\end{tabular}

The table 2. Explores the mean and standard deviation for Performance Appraisal. The highest mean value is 2.73 for the performance appraisal system provides an opportunity for each appraisee to communicate the needs with the superiors to perform the job well through performance review discussions. The lowest standard deviation is 1.0 .50 for the performance appraisal system provides an opportunity for each appraisee to have a clear understanding of what is expected by the reporting officer during the performance year. The lowest mean value is 2.42 and the highest standard deviation is 1.249 for the performance appraisal system encourages the appraiser and appraisee to have a common understanding of the factors affecting the performance of the appraisee. Across the observations, the descriptive statistics for performance appraisal in South Central Railway depicts that the majority of the respondents are agree in opinion with high variation. 
Table-3 Descriptive Statistics for Potential Appraisal

\begin{tabular}{|l|l|l|l|l|l|}
\hline & N & $\begin{array}{l}\text { Minim } \\
\text { um }\end{array}$ & $\begin{array}{l}\text { Maxim } \\
\text { um }\end{array}$ & Mean & SD \\
\hline $\begin{array}{l}11 \text { The railways is creating an opportunity to } \\
\text { each employee discover and utilization }\end{array}$ & 560 & 1 & 5 & 3.02 & .959 \\
potential \\
$\begin{array}{l}\text { 12. The potential appraisal data is used for } \\
\text { other development decisions like job } \\
\text { rotation, job enrichment, transfers, }\end{array}$ \\
$\begin{array}{l}\text { promotions, salary hikes, incentives and } \\
\text { benefits etc. }\end{array}$
\end{tabular}

The table 3. Explores the mean and standard deviation for Potential Appraisal. The highest mean value is 3.77 and the lowest standard deviation is 0.918 for Fosters increased competence, personal growth, and opportunity for career development. The lowest mean values is 2.83 and the highest standard deviation is 1.168 for the railways is investing adequate time and resources for the potential development of employees. Across the observations, the descriptive statistics for potential appraisal in South Central Railway depicts that the majority of the respondents are between neutral and disagree in opinion with high variation. 
Table-4 Descriptive Statistics for Career Development

\begin{tabular}{|c|c|c|c|c|c|}
\hline & $\mathbf{N}$ & $\begin{array}{l}\text { Minim } \\
\text { um }\end{array}$ & $\begin{array}{l}\text { Maxim } \\
\text { um }\end{array}$ & Mean & SD \\
\hline $\begin{array}{l}\text { 16. Railways has a formal policy of career } \\
\text { planning and development and career } \\
\text { opportunities are directed by the seniors }\end{array}$ & 560 & 1 & 5 & 2.91 & 1.124 \\
\hline $\begin{array}{l}\text { 17. The organization's future plans are made } \\
\text { known to the staff to develop and prepare } \\
\text { for the future }\end{array}$ & 560 & 1 & 5 & 3.18 & 1.086 \\
\hline $\begin{array}{l}\text { 18. There are distinct career paths and } \\
\text { internal promotion norms within the } \\
\text { organization }\end{array}$ & 560 & 1 & 5 & 2.90 & 1.116 \\
\hline $\begin{array}{llr}19 & \text { Railways utilizes the assessment } \\
\text { centre/development } & \text { centre for } \\
\text { identification and development of } \\
\text { management potential }\end{array}$ & 560 & 1 & 5 & 2.97 & 1.086 \\
\hline $\begin{array}{l}20 \text { Railways carries out succession planning } \\
\text { in order to ensure that executives are } \\
\text { available to fill gaps in key managerial } \\
\text { positions }\end{array}$ & 560 & 1 & 5 & 3.48 & 1.020 \\
\hline Valid N (listwise) & 560 & & & & \\
\hline
\end{tabular}

The table 4. Explores the mean and standard deviation for Career Development. The highest mean value is 3.48 for Railways carries out succession planning in order to ensure that executives are available to fill gaps in key managerial positions. The lowest mean values is 2.90 for there are distinct career paths and internal promotion norms within the organization. The highest standard deviation is $\mathbf{1 . 1 2 4}$ for Railways has a formal policy of career planning and development and career opportunities are directed by the seniors. The lowest standard deviation is 1.086 for the organization's future plans are made known to the staff to develop and prepare for the future and Railways utilizes the assessment centre/development centre for identification and development of management potential. Across the observations, the descriptive statistics for Career Development in South Central Railway depicts that the majority of the respondents are between neutral and disagree in opinion with high variation. 
Table-5

Descriptive Statistics for Promotions and Transfers

\begin{tabular}{|c|c|c|c|c|c|}
\hline & $\mathbf{N}$ & $\begin{array}{l}\text { Minim } \\
\text { um }\end{array}$ & $\begin{array}{l}\text { Maxim } \\
\text { um }\end{array}$ & Mean & SD \\
\hline $\begin{array}{l}21 \text { Promotions and transfers to different } \\
\text { branches are as per the needs of employees } \\
\text { and Indian Railways }\end{array}$ & 560 & 1 & 5 & 2.51 & 1.297 \\
\hline $\begin{array}{l}\text { 22. Employees are satisfied with the present } \\
\text { promotions and transfers policy }\end{array}$ & 560 & 1 & 5 & 2.17 & 1.238 \\
\hline $\begin{array}{l}\text { 23. Promotions and transfers to different } \\
\text { branches with different designations helps } \\
\text { employees to learn working in different work } \\
\text { environments }\end{array}$ & 560 & 1 & 5 & 2.86 & 1.293 \\
\hline $\begin{array}{l}\text { 24. Promotion and transfer posting } \\
\text { mechanism is effective in placing right } \\
\text { person in right place }\end{array}$ & 560 & 1 & 5 & 2.69 & 1.115 \\
\hline $\begin{array}{l}\text { 25. Promotions are in accordance with the } \\
\text { performance of the job }\end{array}$ & 560 & 1 & 5 & 2.33 & 1.263 \\
\hline Valid N (listwise) & 560 & & & & \\
\hline
\end{tabular}

The table 5. Explores the mean and standard deviation for Promotions and Transfers. The highest mean value is 2 . For Promotions and transfers to different branches with different designations helps employees to learn working in different work environments. The lowest mean values is 2.17 for Employees are satisfied with the present promotions and transfers policy. The highest standard deviation is 1.297 for Promotions and transfers to different branches are as per the needs of employees and Indian Railways. The lowest standard deviation is $\mathbf{1 . 1 1 5}$ for Promotion and transfer posting mechanism is effective in placing right person in right place. Across the observations, the descriptive statistics for Promotions and Transfers in South Central Railway depicts that the majority of the respondents are disagree in opinion with high variation. 
Table-6

Descriptive Statistics for Job Rotation

\begin{tabular}{|c|c|c|c|c|c|}
\hline & $\mathbf{N}$ & $\begin{array}{l}\text { Minim } \\
\text { um }\end{array}$ & $\begin{array}{l}\text { Maxim } \\
\text { um }\end{array}$ & Mean & SD \\
\hline $\begin{array}{l}26 \text { Job rotation provides opportunity to learn } \\
\text { multiple functions/skills and improves job } \\
\text { performance }\end{array}$ & 560 & 1 & 5 & 3.46 & .991 \\
\hline $\begin{array}{l}27 \text { Job rotation reduces the fraud, } \\
\text { manipulation, work load and boredom. }\end{array}$ & 560 & 1 & 5 & 3.77 & .907 \\
\hline $\begin{array}{l}28 \text { Job rotation is done according to the } \\
\text { capabilities of employees and organization's } \\
\text { strategies }\end{array}$ & 560 & 1 & 5 & 3.13 & 1.076 \\
\hline $\begin{array}{l}29 \text { Job rotation leads to understanding and } \\
\text { cooperation between all employees }\end{array}$ & 560 & 1 & 5 & 2.42 & 1.111 \\
\hline $\begin{array}{l}\text { 30. Job rotation is done within the } \\
\text { departments }\end{array}$ & 560 & 2 & 5 & 3.49 & .831 \\
\hline Valid N (listwise) & 560 & & & & \\
\hline
\end{tabular}

The table 6. Depicts the mean and standard deviation for Job Rotation. The highest mean value is 3.77 for Job rotation reduces the fraud, manipulation, work load and boredom. The lowest standard deviation is 0.831 for Job rotation is done within the departments. The lowest mean value is 2.42 and the highest standard deviation is 1.111 for Job rotation leads to understanding and cooperation between all employees. Across the observations, the descriptive statistics for Job Rotation in South Central Railway depicts that the majority of the respondents are neutral in opinion with medium variation. 
One-Way Anova For Hrd With Relation To Nature Of Disability

Table- 7. One-Way ANOVA for Training \& Development and Nature of Disability

\begin{tabular}{|c|c|c|c|c|c|}
\hline & $\begin{array}{l}\text { Sum of } \\
\text { Squares }\end{array}$ & $d f$ & $\begin{array}{l}\text { Mean } \\
\text { Square }\end{array}$ & $F$ & Sig. \\
\hline $\begin{array}{l}1 \text { Knowledge Skills and Attitude are Between Groups } \\
\text { the focus of Training and considers Within Groups } \\
\text { the employee learning needs } \quad \text { Total }\end{array}$ & $\begin{array}{l}32.554 \\
933.989 \\
966.543\end{array}$ & $\begin{array}{l}3 \\
556 \\
559\end{array}$ & $\begin{array}{l}10.851 \\
1.680\end{array}$ & 6.460 & .000 \\
\hline $\begin{array}{ll}2 \text { Training enables employees to } & \text { Between Groups } \\
\text { perform the job effectively } & \text { Total }\end{array}$ & $\begin{array}{l}1.419 \\
785.324 \\
786.743\end{array}$ & $\begin{array}{l}3 \\
556 \\
559\end{array}$ & $\begin{array}{l}.473 \\
1.412\end{array}$ & .335 & .800 \\
\hline $\begin{array}{l}3 \text { Training feedback is given to Between Groups } \\
\text { employees they take it seriously and Within Groups } \\
\text { use it for development }\end{array}$ & $\begin{array}{l}.831 \\
484.552 \\
485.384\end{array}$ & $\begin{array}{l}3 \\
556 \\
559\end{array}$ & $\begin{array}{l}.277 \\
.871\end{array}$ & .318 & .812 \\
\hline $\begin{array}{l}4 \text { The training is effective enough to Between Groups } \\
\text { practice its content on the job with Within Groups } \\
\text { ease } \\
\end{array}$ & $\begin{array}{l}1.140 \\
772.282 \\
773.421\end{array}$ & $\begin{array}{l}3 \\
556 \\
559\end{array}$ & $\begin{array}{l}.380 \\
1.389\end{array}$ & .274 & .044 \\
\hline $\begin{array}{l}5 \text { Employees returning from training Between Groups } \\
\text { programs are given opportunities to Within Groups } \\
\text { try out what they have learned } \quad \text { Total }\end{array}$ & $\begin{array}{l}3.980 \\
774.192 \\
778.171\end{array}$ & $\begin{array}{l}3 \\
556\end{array}$ & $\begin{array}{l}1.327 \\
1.392\end{array}$ & .953 & .045 \\
\hline
\end{tabular}

$\mathrm{H}_{\mathrm{o}}$ : There is no statistically significant difference in the mean opinion on Training \& Development with respect to Nature of disability of the respondents.

The table - 7. One-Way ANOVA Test for training \& development and nature of disability of the respondents reveals:

1. Knowledge Skills and Attitude are the focus of Training and considers the employee learning needs - The null hypothesis $\left(H_{0}\right)$ is rejected. Hence, there is statistically significant difference in the mean opinion on training \& development with respect to nature of disability $F_{(3,556)}=6.460, p=0.000<0.05$. It is concluded that the respondents of South Central Railway are of different opinion with respect to their nature of disability.

2. Training enables employees to perform the job effectively - The null hypothesis $\left(\mathrm{H}_{0}\right)$ is not rejected. Hence, there is no statistically significant difference in the mean opinion on training \& development with respect to nature of disability $F_{(3 \text {, }}$ 556) $=0.335, p=0.800>0.05$. It is concluded that the respondents of South Central Railway are of same opinion with respect to their nature of disability.

3. Training feedback is given to employees they take it seriously and use it for development - The null hypothesis $\left(H_{0}\right)$ is not rejected. Hence, there is no statistically significant difference in the mean opinion on training \& development with respect to nature of disability $F_{(3,556)}=0.318, p=0.812>0.05$. It is concluded 
that the respondents of South Central Railway are of same opinion with respect to their nature of disability.

4. The training is effective enough to practice its content on the job with ease The null hypothesis $\left(H_{0}\right)$ is rejected. Hence, there is statistically significant difference in the mean opinion on training \& development with respect to nature of disability $F(3,556)=0.274, p=0.044<0.05$. It is concluded that the respondents of South Central Railway are of different opinion with respect to their nature of disability.

5. Employees returning from training programs are given opportunities to try out what they have learned - The null hypothesis $\left(\mathrm{H}_{0}\right)$ is rejected. Hence, there is statistically significant difference in the mean opinion on training \& development with respect to nature of disability $F_{(3,556)}=0.953, p=0.045<0.05$. It is concluded that the respondents of South Central Railway are of different opinion with respect to their nature of disability. 
Table- 8. One-Way ANOVA for Performance Appraisal and Nature of Disability

\begin{tabular}{|c|c|c|c|c|c|}
\hline & $\left|\begin{array}{ll}\text { Sum } & \text { of } \\
\text { Squares }\end{array}\right|$ & df & $\begin{array}{l}\text { Mean } \\
\text { Square }\end{array}$ & $F$ & Sig. \\
\hline $\begin{array}{l}6 \text { The performance appraisal system Between Groups } \\
\text { provides an opportunity for each Within Groups } \\
\text { appraisee to have a clear } \\
\text { understanding of what is expected by } \\
\text { the reporting officer during the Total } \\
\text { performance year. }\end{array}$ & $\mid \begin{array}{l}9.064 \\
607.320 \\
616.384\end{array}$ & $\begin{array}{l}3 \\
556\end{array}$ & $\begin{array}{l}3.021 \\
1.092\end{array}$ & 2.766 & .041 \\
\hline $\begin{array}{l}7 \text { The performance appraisal system Between Groups } \\
\text { provides an opportunity for each Within Groups } \\
\text { appraisee to communicate the needs } \\
\text { with the superiors to perform the job } \\
\text { well through performance review Total } \\
\text { discussions }\end{array}$ & $\begin{array}{l}839 \\
868.982 \\
869.821\end{array}$ & $\begin{array}{l}3 \\
556\end{array}$ & $\begin{array}{l}.280 \\
1.563\end{array}$ & .179 & .911 \\
\hline $\begin{array}{l}8 \text { The performance appraisal system Between Groups } \\
\text { encourages the appraiser and Within Groups } \\
\text { appraisee to have a common } \\
\text { understanding of the factors } \\
\text { affecting the performance of the Total } \\
\text { appraisee }\end{array}$ & $\begin{array}{l}1.061 \\
871.481 \\
872.543\end{array}$ & $\begin{array}{l}3 \\
556\end{array}$ & $\begin{array}{l}.354 \\
1.567\end{array}$ & .226 & .879 \\
\hline $\begin{array}{l}9 \text { The performance appraisal system Between Groups } \\
\text { has scope for reflection and Within Groups } \\
\text { assessment of each appraisee on the } \\
\text { personality factors and attributes } \\
\text { required for the present job of the Total } \\
\text { assesse. }\end{array}$ & $\begin{array}{l}4.150 \\
819.271 \\
823.421\end{array}$ & $\begin{array}{l}3 \\
556\end{array}$ & $\begin{array}{l}1.383 \\
1.474\end{array}$ & .939 & .422 \\
\hline $\begin{array}{l}\text { 10The performance appraisal system Between Groups } \\
\text { helps interested appraisees to gain Within Groups } \\
\text { more insights into their strengths and } \\
\text { weaknesses. }\end{array}$ & $\begin{array}{l}12.032 \\
792.189 \\
804.221\end{array} \mid$ & $\begin{array}{l}3 \\
556\end{array}$ & $\begin{array}{l}4.011 \\
1.425\end{array}$ & 2.815 & .039 \\
\hline
\end{tabular}

$\mathrm{H}_{\mathrm{o}}$ : There is no statistically significant difference in the mean opinion on Performance Appraisal with respect to Nature of disability of the respondents.

The table- 8. One-Way ANOVA Test for performance appraisal and nature of disability of the respondents reveals:

1. The performance appraisal system provides an opportunity for each appraisee to have a clear understanding of what is expected by the reporting officer during the performance year.- The null hypothesis $\left(\mathrm{H}_{0}\right)$ is rejected. Hence, there is statistically significant difference in the mean opinion on performance appraisal with respect to nature of disability $F_{(3,556)}=2.766, p=0.041<0.05$. It is 
concluded that the respondents of South Central Railway are of different opinion with respect to their nature of disability.

2. The performance appraisal system provides an opportunity for each appraisee to communicate the needs with the superiors to perform the job well through performance review discussions - The null hypothesis $\left(\mathrm{H}_{0}\right)$ is not rejected. Hence, there is no statistically significant difference in the mean opinion on performance appraisal with respect to nature of disability $F(3,556)=0.179$, $p=0.911>0.05$. It is concluded that the respondents of South Central Railway are of same opinion with respect to their nature of disability.

3. The performance appraisal system encourages the appraiser and appraisee to have a common understanding of the factors affecting the performance of the appraisee - The null hypothesis $\left(\mathrm{H}_{0}\right)$ is not rejected. Hence, there is no statistically significant difference in the mean opinion on performance appraisal with respect to nature of disability $F_{(3,556)}=0.226, p=0.879>0.05$. It is concluded that the respondents of South Central Railway are of same opinion with respect to their nature of disability.

4. The performance appraisal system has scope for reflection and assessment of each appraisee on the personality factors and attributes required for the present job of the assesse. - The null hypothesis $\left(\mathrm{H}_{0}\right)$ is not rejected. Hence, there is no statistically significant difference in the mean opinion on performance appraisal with respect to nature of disability $F_{(3,556)}=0.226, p=0.422>0.05$. It is concluded that the respondents of South Central Railway are of same opinion with respect to their nature of disability.

5. The performance appraisal system helps interested appraisees to gain more insights into their strengths and weaknesses..- The null hypothesis $\left(H_{0}\right)$ is rejected. Hence, there is statistically significant difference in the mean opinion on performance appraisal with respect to nature of disability $F_{(3,556)}=2.815$, $p=0.039<0.05$. It is concluded that the respondents of South Central Railway are of different opinion with respect to their nature of disability. 
Table- 9. One-Way ANOVA for Potential Appraisal and Nature of Disability

\begin{tabular}{|c|c|c|c|c|c|}
\hline & $\begin{array}{l}\text { Sum of } \\
\text { Squares }\end{array}$ & $d f$ & $\begin{array}{l}\text { Mean } \\
\text { Square }\end{array}$ & $F$ & Sig. \\
\hline $\begin{array}{l}11 \text { The railways is creating an Between Groups } \\
\text { opportunity to each employee discover Within Groups } \\
\text { and utilization potential } \\
\end{array}$ & $\begin{array}{l}2.730 \\
511.013 \\
513.743\end{array}$ & $\left|\begin{array}{l}3 \\
556 \\
559\end{array}\right|$ & .910 & .990 & .397 \\
\hline $\begin{array}{l}\text { 12. The potential appraisal data is used Between Groups } \\
\text { for other development decisions like job Within Groups } \\
\text { rotation, job enrichment, transfers, } \\
\text { promotions, salary hikes, incentives and Total } \\
\text { benefits etc. }\end{array}$ & $\begin{array}{l}597 \\
654.687 \\
655.284\end{array}$ & $\left|\begin{array}{l}3 \\
556 \\
559\end{array}\right|$ & $\begin{array}{l}199 \\
1.177\end{array}$ & .169 & .917 \\
\hline $\begin{array}{l}\text { 13. The railways is investing adequate Between Groups } \\
\text { time and resources for the potential Within Groups } \\
\text { development of employees } \\
\end{array}$ & $\begin{array}{l}8.172 \\
754.712 \\
762.884\end{array}$ & $\begin{array}{l}3 \\
556 \\
559\end{array}$ & $\begin{array}{l}2.724 \\
1.357\end{array}$ & 2.007 & .112 \\
\hline $\begin{array}{l}\text { 14. In railways all employees strive to Between Groups } \\
\text { improve potential capabilities according Within Groups } \\
\text { to } \\
\text { Total }\end{array}$ & $\begin{array}{l}2.832 \\
559.867 \\
562.698\end{array}$ & $\begin{array}{l}3 \\
556 \\
559\end{array} \mid$ & $\begin{array}{l}.944 \\
1.007\end{array}$ & .937 & .422 \\
\hline $\begin{array}{l}\text { 15. Fosters increased competence, Between Groups } \\
\text { personal growth, and opportunity for Within Groups } \\
\text { career development } \\
\text { Total }\end{array}$ & $\begin{array}{l}564 \\
470.179 \\
470.743\end{array}$ & $\left|\begin{array}{l}3 \\
556 \\
559\end{array}\right|$ & .188 & .222 & .881 \\
\hline
\end{tabular}

$\mathrm{H}_{\mathrm{o}}$ : There is no statistically significant difference in the mean opinion on Potential Appraisal with respect to Nature of disability of the respondents.

The table-6.51. One-Way ANOVA Test for potential appraisal and nature of disability of the respondents reveals:

1. The railways is creating an opportunity to each employee discover and utilization potential - The null hypothesis $\left(\mathrm{H}_{0}\right)$ is not rejected. Hence, there is no statistically significant difference in the mean opinion on potential appraisal with respect to nature of disability $F_{(3,556)}=0.990, p=0.397>0.05$. It is concluded that the respondents of South Central Railway are of same opinion with respect to their nature of disability.

2. The potential appraisal data is used for other development decisions like job rotation, job enrichment, transfers, promotions, salary hikes, incentives and benefits etc.- The null hypothesis $\left(H_{0}\right)$ is not rejected. Hence, there is no statistically significant difference in the mean opinion on potential appraisal with respect to nature of disability $F(3,556)=0.169, p=0.917>0.05$. It is concluded that the respondents of South Central Railway are of same opinion with respect to their nature of disability.

3. The railways is investing adequate time and resources for the potential development of employees.- The null hypothesis $\left(\mathrm{H}_{0}\right)$ is not rejected. Hence, there is no statistically significant difference in the mean opinion on potential 
appraisal with respect to nature of disability $F_{(3,556)}=2.007, p=0.112>0.05$. It is concluded that the respondents of South Central Railway are of same opinion with respect to their nature of disability.

4. In railways all employees strive to improve potential capabilities according to.The null hypothesis $\left(\mathrm{H}_{0}\right)$ is not rejected. Hence, there is no statistically significant difference in the mean opinion on potential appraisal with respect to nature of disability $F(3,556)=0.937, p=0.422>0.05$. It is concluded that the respondents of South Central Railway are of same opinion with respect to their nature of disability.

5. Fosters increased competence, personal growth, and opportunity for career development.- The null hypothesis $\left(H_{0}\right)$ is not rejected. Hence, there is no statistically significant difference in the mean opinion on potential appraisal with respect to nature of disability $F_{(3,556)}=0.222, p=0.881>0.05$. It is concluded that the respondents of South Central Railway are of same opinion with respect to their nature of disability.

Table- 10. One-Way ANOVA for Career Development and Nature of Disability

\begin{tabular}{|c|c|c|c|c|c|}
\hline & $\mid \begin{array}{l}\text { Sum of } \\
\text { Squares }\end{array}$ & $d f$ & $\begin{array}{l}\text { Mean } \\
\text { Square }\end{array}$ & $F$ & Sig. \\
\hline $\begin{array}{l}\text { 16. Railways has a formal policy of Between Groups } \\
\text { career planning and development Within Groups } \\
\text { and career opportunities are } \\
\text { directed by the seniors }\end{array}$ & $\begin{array}{l}3.374 \\
702.981 \\
706.355\end{array}$ & $\left|\begin{array}{l}3 \\
556 \\
559\end{array}\right|$ & $\begin{array}{l}1.125 \\
1.264\end{array}$ & .890 & .446 \\
\hline $\begin{array}{l}\text { 17. The organization's future plans Between Groups } \\
\text { are made known to the staff to Within Groups } \\
\text { develop and prepare for the future Total }\end{array}$ & $\begin{array}{l}4.671 \\
654.827 \\
659.498\end{array}$ & $\left|\begin{array}{l}3 \\
556 \\
559\end{array}\right|$ & $\begin{array}{l}1.557 \\
1.178\end{array}$ & 1.322 & .266 \\
\hline $\begin{array}{l}\text { 18. There are distinct career paths Between Groups } \\
\text { and internal promotion norms Within Groups } \\
\text { within the organization } \\
\end{array}$ & $\begin{array}{l}1.206 \\
695.194 \\
696.400 \\
\end{array}$ & $\begin{array}{l}3 \\
556 \\
559\end{array} \mid$ & $\begin{array}{l}.402 \\
1.250\end{array}$ & .321 & .810 \\
\hline $\begin{array}{l}19 \text { Railways utilizes the assessment Between Groups } \\
\text { centre/development centre for Within Groups } \\
\text { identification and development of Withen } \\
\text { management potential }\end{array}$ & $\begin{array}{l}.391 \\
659.030 \\
659.421\end{array}$ & $\left|\begin{array}{l}3 \\
556 \\
559\end{array}\right|$ & $\begin{array}{l}.130 \\
1.185\end{array}$ & .110 & .954 \\
\hline $\begin{array}{l}20 \text { Railways carries out succession Between Groups } \\
\text { planning in order to ensure that Within Groups } \\
\text { executives are available to fill gaps Wital } \\
\text { in key managerial positions }\end{array}$ & $\mid \begin{array}{l}5.084 \\
576.614 \\
581.698\end{array}$ & $\left|\begin{array}{l}3 \\
556 \\
559\end{array}\right|$ & $\begin{array}{l}1.695 \\
1.037\end{array}$ & 1.634 & .180 \\
\hline
\end{tabular}

$\mathrm{H}_{\mathrm{o}}$ : There is no statistically significant difference in the mean opinion on Career Development with respect to Nature of disability of the respondents. 
The table-10. One-Way ANOVA Test for career development and nature of disability of the respondents reveals:

1. Railways has a formal policy of career planning and development and career opportunities are directed by the seniors - The null hypothesis $\left(H_{0}\right)$ is not rejected. Hence, there is no statistically significant difference in the mean opinion on career development with respect to nature of disability $F_{(3,556)}=0.890$, $p=0.446>0.05$. It is concluded that the respondents of South Central Railway are of same opinion with respect to their nature of disability.

2. The organization's future plans are made known to the staff to develop and prepare for the future - The null hypothesis $\left(\mathrm{H}_{0}\right)$ is not rejected. Hence, there is no statistically significant difference in the mean opinion on career development with respect to nature of disability $F_{(3,556)}=1.322, p=0.226>0.05$. It is concluded that the respondents of South Central Railway are of same opinion with respect to their nature of disability

3. There are distinct career paths and internal promotion norms within the organization - The null hypothesis $\left(H_{0}\right)$ is not rejected. Hence, there is no statistically significant difference in the mean opinion on career development with respect to nature of disability $F_{(3,556)}=0.321, p=0.810>0.05$. It is concluded that the respondents of South Central Railway are of same opinion with respect to their nature of disability

4. Railways utilizes the assessment centre/development centre for identification and development of management potential - The null hypothesis $\left(H_{0}\right)$ is not rejected. Hence, there is no statistically significant difference in the mean opinion on career development with respect to nature of disability $F_{(3,556)}=0.110$, $p=0.954>0.05$. It is concluded that the respondents of South Central Railway are of same opinion with respect to their nature of disability

5. Railways carries out succession planning in order to ensure that executives are available to fill gaps in key managerial positions - The null hypothesis $\left(H_{0}\right)$ is not rejected. Hence, there is no statistically significant difference in the mean opinion on career development with respect to nature of disability $F_{(3,556)}=1.634$, $p=0.180>0.05$. It is concluded that the respondents of South Central Railway are of same opinion with respect to their nature of disability 
Table- 11. One-Way ANOVA for Promotions \& Transfers and Nature of Disability

\begin{tabular}{|c|c|c|c|c|c|}
\hline & $\begin{array}{l}\text { Sum of } \\
\text { Squares }\end{array}$ & df & $\begin{array}{l}\text { Mean } \\
\text { Square }\end{array}$ & $F$ & Sig. \\
\hline $\begin{array}{l}21 \text { Promotions and transfers to Between Groups } \\
\text { different branches are as per the Within Groups } \\
\text { needs of employees and Indian } \\
\text { Railways }\end{array}$ & $\begin{array}{l}2.243 \\
937.670 \\
939.912\end{array}$ & $\left|\begin{array}{l}3 \\
556 \\
559\end{array}\right|$ & $\begin{array}{l}.748 \\
1.686\end{array}$ & .443 & .022 \\
\hline $\begin{array}{l}\text { 22. Employees are satisfied with the Between Groups } \\
\text { present promotions and transfers Within Groups } \\
\text { policy } \\
\text { Total }\end{array}$ & $\begin{array}{l}6.409 \\
849.812 \\
856.221\end{array}$ & $\left|\begin{array}{l}3 \\
556 \\
559\end{array}\right|$ & $\begin{array}{l}2.136 \\
1.528\end{array}$ & 1.398 & .043 \\
\hline $\begin{array}{l}\text { 23. Promotions and transfers to Between Groups } \\
\text { different branches with different Within Groups } \\
\text { designations helps employees to } \\
\text { learn working in different work Total } \\
\text { environments }\end{array}$ & $\begin{array}{l}13.742 \\
920.829 \\
934.571\end{array}$ & $\left|\begin{array}{l}3 \\
556 \\
559\end{array}\right|$ & $\begin{array}{l}4.581 \\
1.656\end{array}$ & 2.766 & .041 \\
\hline $\begin{array}{l}\text { 24. Promotion and transfer posting Between Groups } \\
\text { mechanism is effective in placing Within Groups } \\
\text { right person in right place } \\
\text { Total }\end{array}$ & $\begin{array}{l}1.785 \\
693.387 \\
695.171\end{array}$ & $\left|\begin{array}{l}3 \\
556 \\
559\end{array}\right|$ & $\begin{array}{l}.595 \\
1.247\end{array}$ & .477. & .038 \\
\hline $\begin{array}{ll}\text { 25. Promotions are in accordance } & \text { Between Groups } \\
\text { with the performance of the job } & \text { Within Groups } \\
& \text { Total }\end{array}$ & $\begin{array}{l}3.980 \\
887.218 \\
891.198\end{array}$ & $\left|\begin{array}{l}556 \\
559\end{array}\right|$ & $\begin{array}{l}1.327 \\
1.596\end{array}$ & .831 & .047 \\
\hline
\end{tabular}

$\mathrm{H}_{\mathrm{o}}$ : There is no statistically significant difference in the mean opinion on Promotions \& Transfers with respect to Nature of disability of the respondents.

The table-11. One-Way ANOVA Test for promotions \& transfers and nature of disability of the respondents reveals:

1. Promotions and transfers to different branches are as per the needs of employees and Indian Railways - The null hypothesis $\left(H_{0}\right)$ is rejected. Hence, there is statistically significant difference in the mean opinion on promotions \& transfers with respect to nature of disability $F(3,556)=0.443, p=0.022<0.05$. It is concluded that the respondents of South Central Railway are of different opinion with respect to their nature of disability.

2. Employees are satisfied with the present promotions and transfers policy - The null hypothesis $\left(H_{0}\right)$ is rejected. Hence, there is statistically significant difference in the mean opinion on promotions \& transfers with respect to nature of disability $F(3,556)=1.398, p=0.043<0.05$. It is concluded that the respondents of South Central Railway are of different opinion with respect to their nature of disability. 
3. Promotions and transfers to different branches with different designations helps employees to learn working in different work environments - The null hypothesis $\left(\mathrm{H}_{0}\right)$ is rejected. Hence, there is statistically significant difference in the mean opinion on promotions $\&$ transfers with respect to nature of disability $F(3,556)=2.766, p=0.041<0.05$. It is concluded that the respondents of South Central Railway are of different opinion with respect to their nature of disability.

4. Promotions and transfers to different branches with different designations helps employees to learn working in different work environments - The null hypothesis $\left(\mathrm{H}_{0}\right)$ is rejected. Hence, there is statistically significant difference in the mean opinion on promotions $\&$ transfers with respect to nature of disability $F(3,556)=0.477, p=0.038<0.05$. It is concluded that the respondents of South Central Railway are of different opinion with respect to their nature of disability.

5. Promotions are in accordance with the performance of the job - The null hypothesis $\left(H_{0}\right)$ is rejected. Hence, there is statistically significant difference in the mean opinion on promotions $\&$ transfers with respect to nature of disability $F_{(3,556)}=0.831, p=0.047<0.05$. It is concluded that the respondents of South Central Railway are of different opinion with respect to their nature of disability.

Table- 6.12. One-Way ANOVA for Job Rotation and Nature of Disability

\begin{tabular}{|c|c|c|c|c|c|}
\hline & $\begin{array}{l}\text { Sum of } \\
\text { Squares }\end{array}$ & Df & $\begin{array}{l}\text { Mean } \\
\text { Square }\end{array}$ & $\mathrm{F}$ & Sig. \\
\hline $\begin{array}{l}26 \text { Job rotation provides opportunity } \\
\text { to learn multiple functions/skills and Within Groups } \\
\text { improves job performance }\end{array}$ & $\mid \begin{array}{l}3.510 \\
545.546 \\
549.055\end{array}$ & $\begin{array}{l}3 \\
556 \\
559\end{array}$ & $\begin{array}{l}1.170 \\
.981\end{array}$ & 1.192 & .312 \\
\hline $\begin{array}{l}27 \text { Job rotation reduces the fraud, Between Groups } \\
\text { manipulation, work load and Within Groups } \\
\text { boredom. } \\
\text { Total }\end{array}$ & $\mid \begin{array}{l}7.896 \\
451.926 \\
459.821\end{array}$ & $\begin{array}{l}3 \\
556 \\
559\end{array}$ & $\begin{array}{l}2.632 \\
.813\end{array}$ & 3.238 & .022 \\
\hline $\begin{array}{l}28 \text { Job rotation is done according to Between Groups } \\
\text { the capabilities of employees and Within Groups } \\
\text { organization's strategies } \\
\end{array}$ & $\begin{array}{l}24.079 \\
622.877 \\
646.955\end{array}$ & $\begin{array}{l}3 \\
556 \\
559\end{array}$ & $\begin{array}{l}8.026 \\
1.120\end{array}$ & 7.164 & .000 \\
\hline $\begin{array}{l}29 \text { Job rotation leads to Between Groups } \\
\text { understanding and cooperation Within Groups } \\
\text { between all employees } \\
\end{array}$ & $\begin{array}{l}5.596 \\
684.625 \\
690.221\end{array}$ & $\begin{array}{l}3 \\
556 \\
559\end{array}$ & $\begin{array}{l}1.865 \\
1.231\end{array}$ & 1.515 & .210 \\
\hline 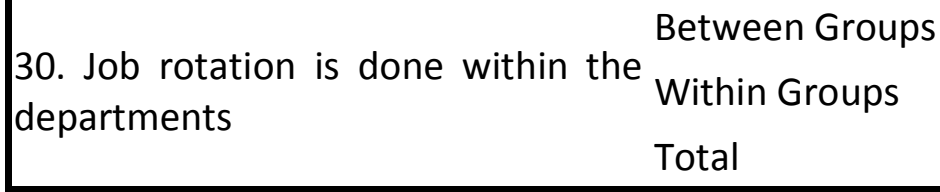 & $\begin{array}{l}2.277 \\
383.694 \\
385.971\end{array}$ & $\begin{array}{l}556 \\
559\end{array}$ & $\begin{array}{l}.759 \\
.690\end{array}$ & 1.100 & .349 \\
\hline
\end{tabular}

$\mathrm{H}_{\mathrm{o}}$ : There is no statistically significant difference in the mean opinion on Job Rotation with respect to Nature of disability of the respondents. 
The table-12. One-Way ANOVA Test for job rotation and nature of disability of the respondents reveals:

1. Job rotation provides opportunity to learn multiple functions/skills and improves job performance - The null hypothesis $\left(H_{0}\right)$ is not rejected. Hence, there is no statistically significant difference in the mean opinion on job rotation with respect to nature of disability $F_{(3,556)}=1.192, p=0.312>0.05$. It is concluded that the respondents of South Central Railway are of same opinion with respect to their nature of disability.

2. Job rotation reduces the fraud, manipulation, work load and boredom.- The null hypothesis $\left(\mathrm{H}_{0}\right)$ is rejected. Hence, there is statistically significant difference in the mean opinion on promotions \& transfers with respect to nature of disability $F_{(3,556)}=3.238, p=0.022<0.05$. It is concluded that the respondents of South Central Railway are of different opinion with respect to their nature of disability.

3. Job rotation is done according to the capabilities of employees and organization's strategies.- The null hypothesis $\left(\mathrm{H}_{0}\right)$ is rejected. Hence, there is statistically significant difference in the mean opinion on promotions $\&$ transfers with respect to nature of disability $F(3,556)=7.164, p=0.000<0.05$. It is concluded that the respondents of South Central Railway are of different opinion with respect to their nature of disability.

4. Job rotation leads to understanding and cooperation between all employees The null hypothesis $\left(\mathrm{H}_{0}\right)$ is not rejected. Hence, there is no statistically significant difference in the mean opinion on job rotation with respect to nature of disability $F_{(3,556)}=1.515, p=0.210>0.05$. It is concluded that the respondents of South Central Railway are of same opinion with respect to their nature of disability.

5. Job rotation is done within the departments - The null hypothesis $\left(\mathrm{H}_{0}\right)$ is not rejected. Hence, there is no statistically significant difference in the mean opinion on job rotation with respect to nature of disability $F_{(3,556)}=1.100$, $p=0.349>0.05$. It is concluded that the respondents of South Central Railway are of same opinion with respect to their nature of disability.

\section{Findings of the present study}

\section{Training \& Development}

- Knowledge, Skills and Attitude are the focus of Training and considers the employee learning needs - the total majority $30.9 \%$ of the respondents disagreed and the chi-square test reveals that it is not statistically associated with the nature of disability.

- Training enables employees to perform the job effectively - the total majority $41.8 \%$ of the respondents disagreed and the chi-square test reveals that it is not statistically associated with the nature of disability.

- Training feedback is given to employees, they take it seriously and use it for development - the total majority $52.9 \%$ of the respondents are neutral in opinion and the chi-square test reveals that it is statistically associated with the nature of disability. 
- The training is effective enough to practice its content on the job with ease - the total majority $34.5 \%$ of the respondents disagree, $33.4 \%$ of the respondents strongly disagreed and the chi-square test reveals that it is not statistically associated with the nature of disability.

- Employees returning from training programs are given opportunities to try out what they have learned - the total majority $37.9 \%$ of the respondents are neutral in opinion and the chi-square test reveals that it is not statistically associated with the nature of disability.

\section{Performance Appraisal}

- The performance appraisal system provides an opportunity for each appraisee to have a clear understanding of what is expected by the reporting officer during the performance year - the total majority $33.8 \%$ of the respondents are neutral opinion and the chi-square test reveals that it is not statistically associated with the nature of disability.

- The performance appraisal system provides an opportunity for each appraisee to communicate the needs with the superiors to perform the job well through performance review discussions - the total majority $29.1 \%$ of the respondents are neutral opinion and the chi-square test reveals that it is not statistically associated with the nature of disability.

- The performance appraisal system encourages the appraiser and appraisee to have a common understanding of the factors affecting the performance of the appraise - the total majority $28.9 \%$ of the respondents disagreed and the chisquare test reveals that it is not statistically associated with the nature of disability.

- The performance appraisal system has a scope for reflection and assessment of each appraisee on the personality factors and attributes required for the present job of the assesse - the total majority $32.1 \%$ of the respondents disagreed and the chi-square test reveals that it is not statistically associated with the nature of disability.

- The performance appraisal system helps interested appraisees to gain more insights into their strengths and weaknesses - the total majority $34.5 \%$ of the respondents disagrees and the chi-square test reveals that it is statistically associated with the nature of disability.

\section{Potential Appraisal}

- Creating an opportunity to each employee to discover and utilize potential - the total majority $53.8 \%$ of the respondents are neutral in opinion and the chi-square test reveals that it is statistically associated with the nature of disability.

- The potential appraisal data is used for other development decisions like job rotation, job enrichment, transfers, promotions, salary hikes, incentives and benefits etc. - the total majority $43.6 \%$ of the respondents are neutral opinion and the chi-square test reveals that it is not statistically associated with the nature of disability. 
- Investing adequate time and resources for the potential development of employees - the total majority $34.3 \%$ of the respondents are neutral opinion and the chi-square test reveals that it is not statistically associated with the nature of disability.

- All employees strive to improve potential capabilities according to - the total majority $42.3 \%$ of the respondents are neutral in opinion and the chi-square test reveals that it is not statistically associated with the nature of disability.

- Potential Appraisal Fosters increased competence, personal growth, and opportunity for career development - the total majority $37.7 \%$ of the respondents agreed and the chi-square test reveals that it is not statistically associated with the nature of disability.

\section{Career Development}

- Formal policy of career planning and development and career opportunities are directed by the seniors - the total majority $41.6 \%$ of the respondents are neutral in opinion and the chi-square test reveals that it is not statistically associated with the nature of disability.

- The organization's future plans are made known to the staff to develop and prepare for the future - the total majority $41.8 \%$ of the respondents are neutral in opinion and the chi-square test reveals that it is not statistically associated with the nature of disability.

- There are distinct career paths and internal promotion norms within the organization - the total majority $34.1 \%$ of the respondents are neutral in opinion and the chi-square test reveals that it is not statistically associated with the nature of disability.

- Utilizes the assessment center/development center for identification and development of management potential - the total majority $37.9 \%$ of the respondents are neutral in opinion and the chi-square test reveals that it is not statistically associated with the nature of disability.

- Carries out succession planning in order to ensure that the executives are available to fill the gaps in key managerial positions - the total majority $35.0 \%$ of the respondents are neutral in opinion and the chi-square test reveals that it is not statistically associated with the nature of disability.

\section{Promotions and Transfers}

- Promotions and transfers to different branches are as per the needs of employees - the total majority $34.5 \%$ of the respondents disagreed and the chisquare test reveals that it is not statistically associated with the nature of disability.

- Employees are satisfied with the present promotions and transfers policy - the total majority $37.5 \%$ of the respondents strongly disagreed and the chi-square test reveals that it is not statistically associated with the nature of disability.

- Promotions and transfers to different branches with different designations help employees to learn working in different work environments - the total majority 
$25.4 \%$ of the respondents disagreed and the chi-square test reveals that it is statistically associated with the nature of disability.

- Promotion and transfer posting mechanism is effective in placing the right person in the right place - the total majority $36.1 \%$ of the respondents are neutral in opinion and the chi-square test reveals that it is not statistically associated with the nature of disability.

- Promotions are in accordance with the performance of the job - The total majority $33.6 \%$ of the respondents disagreed and the chi-square test reveals that it is not statistically associated with the nature of disability.

\section{Job Rotation}

- Job rotation provides opportunity to learn multiple functions/skills and improves job performance - the total majority $45.2 \%$ of the respondents are neutral in opinion and the chi-square test reveals that it is not statistically associated with the nature of disability.

- Job rotation reduces the fraud, manipulation, work load and boredom - the total majority $41.6 \%$ of the respondents agreed and the chi-square test reveals that it is not statistically associated with the nature of disability.

- Job rotation is done according to the capabilities of employees and organization's strategies - the total majority $49.1 \%$ of the respondents are neutral in opinion and the chi-square test reveals that it is statistically associated with the nature of disability.

- Job rotation leads to understanding and cooperation between all employees the total majority $40.2 \%$ of the respondents disagreed and the chi-square test reveals that it is statistically associated with the nature of disability.

- Job rotation is done within the departments - the total majority $56.1 \%$ of the respondents are neutral in opinion and the chi-square test reveals that it is statistically associated with the nature of disability.

\section{Conclusion}

The responses of the respondents on overall human resource development activities that are taking place in the South Central Railway. The variables of the HRD are training and development, performance appraisal, potential appraisal, career development, promotions and transfers and job rotation. The frequency distribution followed by Descriptive Statistics, one-way ANOVA with experience and nature of disability has been used. The analysis results that the most of the respondents are neutral in opinion in all the aspects of potential appraisal, career development and job rotation. They disagree with some of the aspects of training and development, performance appraisal and promotions and transfers. They are not satisfied with the promotions and transfers taking place in the organization as the respondents are expecting promotions according to their educational qualifications, performance and potential capabilities. 


\section{References}

1. Human Resource Management, Raymond A Noe and Patrick McGraw hill, COMPANIES, INC, 1997.

2. Personnel Management by C.B. Mamoria. Himalaya publications, New Delhi.

3. Statistical Techniques of Manpower Planning and Forecasting Suddhendu Biswas, 1996, New Age International Polishers. New Delhi.

4. TRIPATHI P.C.,"Human Resource Development": Sultan Chand and Sons, 2010, Pg. no. 44

5. OVASDI J. M., "Railway Administration and Management": Deep and Deep, 1990, Pg. no. 215 Reports [6]. Indian Railways--Annual Report and Accounts, Ministry of Railways, Government of India.

6. Indian Railways Year Books, Ministry of Railways, Government of India.

7. Report by V.K.Agarwal, Chairman Railway Board

8. Report of Indian Defence Analysis

9. Report of Indian Railways

Websites

10. www.preservearticles.com

11. www.essaydepot.com 
102 Human Resource Development Policies For Pwd...... 